\title{
Assessment of residential housing choices, quality, and affordability in Calabar Metropolis, Southern Nigeria \\ Inah Eteng Okon ${ }^{1 *}$, Mark Egbe Ikelegu ${ }^{2}$ \\ ${ }^{1 *}$ Associate Professor, Department of Geography and Environmental Science, University of Calabar, Calabar, PMB 1115, Calabar, Nigeria; ${ }^{2}$ PhD Candidate, Department of Geography and Environmental Science, University of Calabar, Calabar, Nigeria. \\ Email: 1"inah.okon@unical.edu.ng, 2ikelegumark@gmail.com
}

\author{
Keywords \\ Housing, Housing Quality, Housing \\ Affordability, Residential Housing Choice, \\ Housing Adequacy, Socioeconomic \\ Characteristics. \\ Article History \\ Received on $4^{\text {th }}$ August 2021 \\ Accepted on $19^{\text {th }}$ September 2021 \\ Published on $23^{\text {rd }}$ September 2021 \\ Cite this article \\ Okon, I. E., \& Ikelegu, M. E. (2021). \\ Assessment of residential housing choices, \\ quality, and affordability in Calabar Metropolis, \\ Southern Nigeria. Humanities \& Social Sciences \\ Reviews, 9(5), 35-46. \\ https://doi.org/10.18510/hssr.2021.956
}

Copyright @Author

Publishing License

This work is licensed under a Creative

Commons Attribution-Share Alike 4.0

International License

\begin{abstract}
Purpose of the study: This paper examined the housing quality, its affordability as well as the housing choices which residents of Calabar can make. Housing needs in the city continue to rise in response to rapid urbanization rates and thus lead to high housing demands.

Methodology: About 384 questionnaires were distributed randomly within six purposively delineated housing districts in Calabar with a 78 percent success rate. The stratification covered all the housing types, from the low to medium and the high classes. The coordinates of respondents were also collected for spatial analyses in which the inverse distance weighted (IDW) interpolation method was used to create housing choice maps in the identified districts of the city. The Chi-square statistics were used to test the statistical significance of the created contingency tables.
\end{abstract}

Main Findings: Significant relationship exist between housing affordability and housing quality $((f)=11.463$, $p$-value $=0.022(p<0.05))$, and between average monthly income and expenditure on rented residential housing in Calabar $((f)=539.473$, $p$-value $=0.000(p<0.05))$. Housing in the metropolis is not affordable to about $80 \%$ of residents who expend more than $30 \%$ of their income on housing.

Applications of this study: This study helps shape the policy direction of government in housing provision and such, encourage private developers in the sector.

Novelty/Originality of this study: Previous studies only addressed housing cost and provision, not a choice, quality, and affordability. This is the first study to address residential housing choices, quality, and affordability in the Calabar metropolis, involving a cross-sectional survey questionnaire. The results will be helpful to developers, homebuyers, and policymakers alike towards affordable housing delivery in Calabar and others. African cities.

\section{INTRODUCTION}

The current existence of deplorable housing conditions and costs is a reality that cannot be overlooked. As the population increases, lesser people are availed of basic needs such as adequate sanitation, improved water supply, durable and affordable housing, and adequate living space. The absence of these primary conditions has direct consequences on the physical and psychological wellbeing of urban populations. Globally, urbanization is increasing. The rate of increase in Nigeria is high within the last two decades. In Nigeria, data from the census in the early fifties had revealed how approximately 11 percent of the total population lived in about 56 cities. In the 1963 census, there was a dramatic rise in this number to about 19 percent in just over 100 cities. The urban population increased to 24.5 percent in 1985 and was estimated to be more than 30 percent in the 1996 census (Ajanlekoko, 2001).

Housing is said to be affordable when its cost does not necessarily compromise the ability to meet other essential household needs such as food, clothing, and health care. Struky (2005) defined affordable housing as the ability to buy a reasonably standard house without compromising the ability to meet the demands of other essential needs. No nation has ever been known to have fully provided shelter for all its citizens. In most developed countries of the world, priority attention had never been to housing as a deliberate action to continue a national program that emanates from a wellarticulated housing policy.

Many scholars have attempted various definitions of housing in different contexts. For example, Kalu, Agbarakwe, and Anowor (2014) defined housing as homes, shelters, dwelling places, or buildings where people dwell or live, which was used to define households' standard of living. This provides a measure of the status of individuals or families as this is known to have a relationship with health, productivity, and personal wellbeing. This is why there is a constant argument that housing must not only be available but must also be affordable. The affordability criteria are a measure of housing cost, environmental factors, standards, cost of mortgages, and other essentials. Affordable housing is critical for the socio-economic, socio-cultural, socio-political, and national development of any nation. It enhances safety from 
imminent threats such as invaders, weather, and climate. Housing is has a huge influence on the efficiency and stability of national economies and thus defines the direction of financial markets with huge impacts on the productivity and growth of nations. Bujang (2006) observed that the affordability of housing is compromised when more than 30 percent of the household income of those within the low-income group is spent on housing.

This study is focused on the urban housing sector of Calabar, Cross River State, Nigeria. Calabar is the capital city of Cross River State in south-south Nigeria and is made up of mainly Calabar South and Calabar Municipality Local Government Areas (LGA). As shown in figure 1, the city lies between longitudes $8^{0} 18^{1} 00^{11} \mathrm{E}$ to $8^{0} 24^{1} 00^{11} \mathrm{E}$ and latitudes $4^{0} 54^{1} 00^{11} \mathrm{~N}$ to $5^{0} 04^{1} 00^{11} \mathrm{~N}$ and covers a land area of 137.039 square kilometers (sqm) and has an estimated population of 435,196 in 2016 (NPC, 2006). The residential land uses cut across the three hierarchical density variations; the low, medium, and high-income densities. Examples of such areas include and are not limited to the high densities in Calabar South LGA, which includes, Mount Zion, Goldie, etc. Medium densities include, Parliamentary Village, Ikot Effa, etc., while the low-density areas are of Federal Housing, State Housing, etc.

The requirement of housing for comfort, safety, experience, prestige, satisfaction, and the occupant's convenience remain a global consensus. This is why it has remained a vital social condition that defines the living standard of a country's citizens. When the quality of housing is available and adequate, capital expenditure on health, recreation, crime prevention, and pollution control is less from residents and government alike, and often enhances productivity and prosperity (Olanrewaju \& Woon, 2017; Gan, Zuo, Wen \& She, 2019). The lack of or inadequacy of housing, usually a consequence of high rates of urbanization, has resulted in its high demand and poor quality (Demographia World Urban Areas, 2017; Gan et al., 2017).

Housing problems across Calabar is exacerbated by low investment in medium and low-income housing by both the private sector and government. Field observations showed how the private developers control most of the land which they are only interested in developing for luxury apartments, obviously beyond the affordability of the majority of urban dwellers. This leads to a housing crisis in the city with huge environmental consequences in terms of urban dwellers resorting to self-help for accommodation. Animashaun (2010) observed that the problem goes from residential housing adequacy to housing quality which he concluded has social, psychological, environmental, and cultural impacts on dwellers. The housing quality debate in Calabar and Nigeria continues unabated as the nations are yet to successfully implement any social housing since the first national development framework. The study aimed at assessing the socioeconomic impacts of rent, the relationship between the affordability of rent and housing quality as well as between income and expenditure on housing. It further invested the considerations for rented residential housing choice in specific districts of Calabar.

\section{LITERATURE REVIEW}

Housing has been defined in different ways by various authors. According to Omole (2001), housing is more than a mere shelter, but rather emphasized housing as a residential environment that man uses for shelter. He also described it as a structure needed or designed for man's physical and mental health as well as his social well-being. For Onibokun (1985), housing represents a basic individual, family/household or community need that is essential for the survival of man ranked only second to food needs. In addition to being a prerequisite for survival, housing is also noted to be an environmental component with a high influence on social behaviour, health, satisfaction, efficiency, and economic value of a society. Essentially, there have been financial evaluations of demand for affordable housing in many countries, however, concerns are rife on the fact that affordable housing cannot be limited to mere economic concepts since housing issues cut across social wellbeing and matters of sustainability (Ezennia \& Hoskara, 2019; Adabre \& Chan, 2019). For example, Bons, Onochie \& Nzewi (2019) reported the difficulty of low and medium-income residents of Abuja (Nigeria) to afford decent and adequate accommodation. This often leaves them with no choice but to reside in squatters or infringes where the cost of transport to employment opportunities becomes unbearable. Earlier studies reported a housing deficit for over 20 million urban dwellers in Asia, Africa, and South America who often reside in slums or squatter housing. In Nigeria, the situation is more challenging as most urban residents live in sub-standard housing in slums (Makinde, 2014). This is in addition to Geissler, Österreicher \& Macharm (2018) report that there is a deficit of 17 million housing units in Nigerian urban centres.

The affordability of housing often refers to the capacity of an individual, family/household, or community to pay for housing costs/services. It impacts significantly on the general environment, economy, and social conditions of any city, country, or region. Yao (2011) defined housing affordability as the relationship between households and housing. In the same vein, housing affordability is expressive of the balance of payment challenges that individuals or households face between non-housing expenditures and the cost of actual or potential housing (Stone, 2006). It is the correlation between the individual or household income and actual expenditure on housing (Kutty, 2005). This is why housing expenditure must not exceed 30 percent of individual/household income otherwise, an indication of a huge financial burden or lack of capacity to meet up with other basic needs such as food, clothing, healthcare, and transportation (Bujang, 2006). Using a cross-sectional survey questionnaire, comprising 20 determinants and 468 householders/users, Olanrewaju and Woon (2019) explained the six determinants that are extremely important to households' choice of housing. These determinants include financial factor, building factor, income factor, accessibility factor, market factor, and location factor. 


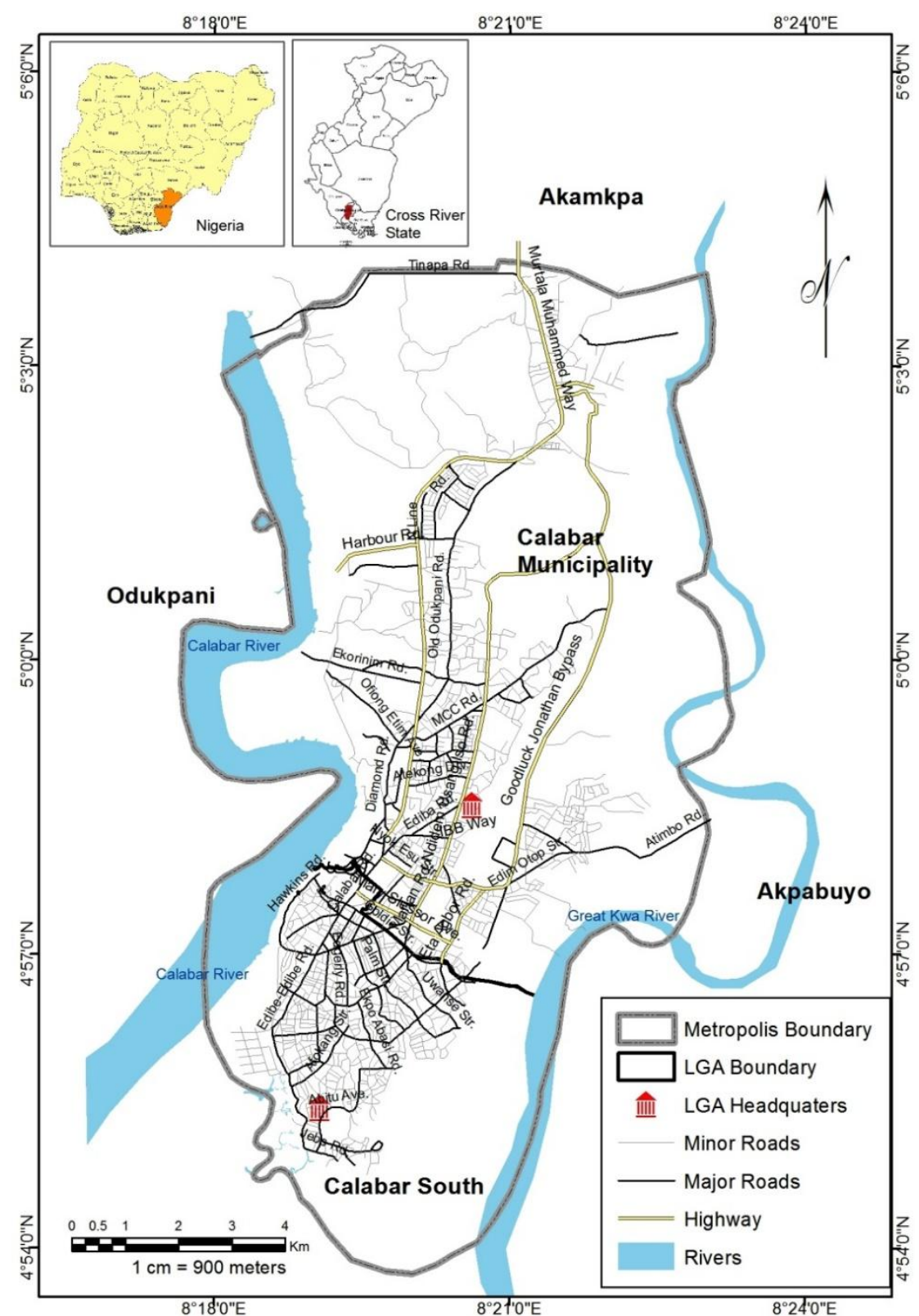

Figure 1: Calabar metropolis showing major streets; Insert: Nigeria showing Cross River; and Cross River showing Calabar Metropolis.

Source: GIS Unit, Department of Geography/Environmental Science, University of Calabar.

Countries of the Third Word are experiencing pervasive housing deficits. Omojinmi (2000) observed that a higher percentage of the urban residents in Nigeria dwells in indecent housing units compared to those living in good houses. The increasing rate of urbanization in Nigeria like in other Third World countries rather compounds the already bad housing situation. Beyond the rising rate of urbanization and migration (in most cases, conflict-induced migration), the high rate of inflation leading to the high cost of building materials and construction cost accounts for a significant cause of this housing deficit (Olotuah \& Adedeji, 2009). Using multiple regression analysis, Agbor, Ojikpong, Okon, \& Obia (2016) revealed a poor-quality housing environment for Ikom Urban that is typical of poor or dilapidated housing units which lack basic services and facilities. The 'housing-related urban poverty' study of Ojoko and Okon (2018) also revealed a corresponding relationship $(\mathrm{F}(6,402)=8.903, p<.001$.) between residential mobility and demographic factors such as job type, household size, marital status, annual income, education, and gender. The need for mass housing provision for low income was highlighted. Similarly, Okon, Ogba, and Adejumo (2012) identified three categories of land ownership such as patrimony, occupier, and investment which indicated different economic behaviour using the methodology provided in the CASHPOR House Index $(\mathrm{CHI})$. The paper recommended preventive and curative strategies towards informal settlements including sites and services, land readjustment, review of the land use act of 1978, among others. Ayedun and Oluwatobi (2011) reported the opinion of the 1976 United Nations Conference on Human Settlements that suggested a multi-faceted approach to addressing the hydra-headed housing problems, especially in developing countries. Part of the details of this proposed policy was the provision of housing schemes for low-income earners through different levels of loans and other incentives from international organizations. However, the failure of the implementation phase of this program has been reported in Nigeria and many other developing countries. 
Zyed, Aziz, and Hanif (2016) reported the central role that Housing choice plays in offering an understanding of the economic status of households and their housing rent purchasing capability. Therefore, the housing affordability problem concerning housing choice which can be viewed in terms of purchasing perspective as contained in the right to housing framework, which government must guarantee for the comfort of individuals and households. This is bearing in mind the dynamicity of preferences and choices in any given society, which is also a reflection of the pattern of behaviour of the people. However similar to these housing preferences and choices may be, most housing literature uses both terms interchangeably (Zinas \& Jusan, 2012; Kährik, Temelova, Kadarik \& Kubes, 2016).

Zinas \& Jusan (2012) identified how need and demand are based on choice but not as important, as much as consumers like the good. However, they may prefer a good or service independent of the existence of alternatives (Olanrewaju \& woon, 2017). According to Sirgy, Grzeskowiak, \& Su, (2005) 'choice is the description of consumers' attitude and behavior'. As the price of the goods/services increases, the consumption rate tends to fall according to the law of demand (Napoli, 2017). Therefore, the choice of housing more often is determined by price rather than by preference. The choice remains a vital determinant upon which prices of houses are determined (Parkin, 2011; Karlan \& Morduch, 2014; O'Sullivan, Sheffrin \& Perez, 2013). While the differences between choice and preference can be complicated, housing choice usually reflects one or a combination of regulation, preference, availability, market condition, and/or internal/external factors such as lifestyle and social class (Jansen, Coolen \& Goetgeluk, 2011). On the other hand, Housing preference does not usually highlight choice behavior according to Ghazali, Ngiam \& Mutum (2019).

While the focus of this research is not on sustainable development, it is important to remark on recent research evidence that points to the low knowledge of the concept of sustainable development (Olanrewaju, Tan \& Abdul-Aziz, 2018). It implies the efficient use of natural resources in a manner that satisfies the present need as well as guarantees its future use for generations yet to come. This engenders peace across the social spectrum and maintains stable economic growth and environmental quality when applied to affordable housing (Vehbi, Hoskara \& Hoskara, 2010). Sustainable development in affordable housing is usually premised on the three major objectives, such as environmental, social, and economic goals. The integration of sustainability and affordability into housing often referred to as sustainable affordable housing has been advocated by several housing experts (Adabre \& Chan, 2019; Ghazali, Ngiam \& Mutum, 2019; Chan \& Adabre, 2019). This is because sustainable affordable housing just as sustainable development will meet the present need of housing with a guarantee that future generations' housing needs will not be compromised. It is therefore said to be housing designed and implemented to satisfy sustainable requirements (Ezennia \& Hoskara, 2019; Adabre \& Chan, 2019; Mulliner \& Maliene, 2015). In Nigeria and many other countries of the developing world, there is a widened affordable housing gap which is due largely to income inequality and imbalance.

"Our Common Future" produced by the Brundtland Commission for the United Nations (World Commission on Environment and Development, 1987) remains a serious expression of the concerns that the world has towards the environment. If the environment remains where we live, and development is what we do on the environment for our enjoyment, therefore, there is the moral burden to reflect on the future use of these same resources by future generations. Buildings or the built environment have a significant impact on the quality of life (Akintoye, 2006). Sustainable development deals with housing quality, affordability, availability, and accessibility, addressing social justice and equity in housing provision. This calls for an assessment of the life cycle of housing provision in such a manner that the basic concepts of affordability, quality, and accessibility (access) as was the concern of this paper, must be addressed.

\section{METHODOLOGY}

Data was obtained from primary and secondary sources. While the secondary data included excerpts from existing literature and publications, the cross-sectional research was adopted for primary data collection among the varying socio-economic backgrounds and ages in the metropolis. Data was collected from residents within the Calabar metropolis. A total of 384 questionnaires were administered in line with Smith (2000) and Saunders, Lewis, and Thornhill (2007) based on the metropolis population of 435,196 $(<1,000,000)$, and 300 were successfully retrieved $(78$ percent success rate). The questionnaires were distributed randomly within 6 purposively delineated housing districts in Calabar. The districts and their case studies as presented in figure 2 include: (a) Commercial settlement, case study: Marian (b) Traditional settlement, case study: Ikot Ansa (c) Hybrid settlement, case study: Ekorinum (d) High-income settlement, case study: Federal Housing Estate (e) Medium income settlement, case study: Parliamentary and (f) lowincome settlement, case study: Ekpo Abasi area. The district stratification covered all the classes of income and settlement structures, from the low to medium and the high classes. The data was collected on household income, age, sex, household size, educational attainment, location and occupation of respondents, housing affordability, and factors that affect the geographic variation in rental housing affordability rate across the metropolis. The coordinates of questionnaire administration locations were also collected for spatial analyses.

For the data analyses, cross-tabulation analyses were done to establish the relationships between variables, and Chisquare statistics was used to test the statistical significance of the contingency tables created. The Inverse Distance Weighted (IDW) interpolation method was used to create housing choice maps based on attribute data obtained from a field survey of identified districts of the metropolis. This works with the assumption that things close together to share certain similarities (ESRI, 2013). 


\section{RESULTS/FINDINGS}

\section{(a) Housing Quality Components in Calabar}

The analyses indicate that 8.2 percent of the respondents had no formal education while 91.8 percent had passed through at least the primary level of formal schooling. This implies that most residents are literate and could provide precise and adequate information on the questionnaire relating to the subject of investigation. Also, inquiry into the income structure of the respondents revealed that 50.3 percent of the residents make less than 10,000 Naira monthly, 30 percent make between 51,000 to 100,000 Naira monthly, 10 percent accrue between 101,000 to $150,000,6$ percent get 150,000 to 200,000 Naira. In comparison, 2.3 percent make more than 200,000 Naira income on average monthly. This is a clear indication that housing affordability would most likely be relatively complex for low-income earners.

Housing quality components were assessed considering the Statistic New Zealand (2015) housing quality indicators. These components incorporate the status quo of the internal structure such as the condition of water supply, sewage disposal, power supply, door type, wall type, electrical wiring, etc. also is the condition of the external structure like the structural integrity, weather tightness, security, material integrity, insulation, etc. The housing type that is predominant in Calabar, according to findings is the one-bedroom flat with 35 percent of all the responses. Single room residents made up to 23.3 percent mostly in the Ekpo-Abasi district. In comparison, 221 percent of residents stayed in 2-bedroom flats and 14.6 percent in 3-bedroom flats which most of Parliamentary and Ekorinim residents patronize. In the Federal housing district where conspicuously high-income earners reside, 5 percent of the respondents live in duplexes.

Furthermore, 63.3 percent of residents sampled have wooden doors, while 32 percent stayed in houses with iron doors, and 4 percent went for soundproof doors. Also, 9.2 percent of residents had walls made of wood, metal and, other shanty slum characterized materials. In comparison, 31.6 percent stay in houses with brick walls and 59.3 percent reside in homes with concrete walls housing. In the same vein, 24 percent of homes in the study area had wooden windows fixed, 9 percent used metal fabricated windows and 67 percent used glass windows across the metropolis, which is of higher quality.

Hygiene was revealed to be improved in the city in 2016, although there is a need for more improvements. Only 2 percent of the respondents used pit toilets, 1.6 percent used bucket toilets, 73 percent used water closets, and 19.6 percent adopted open defecation in open spaces and water bodies around their vicinity. Also, the analysis showed that 67.6 percent rely primarily on water from boreholes in their compounds and neighbourhood, while 27 percent rely on the government-supplied water and 4.6 use other sources such as water vendors, wells, and streams. Additionally, 55.3 percent of residents dispose of their solid waste properly in the Cross River State Urban Development Authority waste collection bins while 30.3 percent use waste dumps, most of which are eventually evacuated by the same government authority, and 14.3 percent burn and incinerate their wastes. As well, 35 percent of the residents mostly use personally powered electricity generators for power supply while 64.3 percent depending on the Power Holding Company of Nigeria.

\section{Housing Affordability in Calabar}

The field survey further revealed that housing in the metropolis is unaffordable if we adopt the affordability criteria where only 30 percent of income should be spent on housing. As derived, 20.7 percent of residents use less than 30 percent of their income for housing while 79.3 percent use more than 30 percent of their income for housing. It was revealed that 7.6 percent could afford less than 50,000 Naira for housing annually, 22 percent can afford between 50,000 to 100,000 Naira, 46.6 percent between 101,000 to 200,000 Naira annually, 13 percent between 201,000 to 300,000 Naira. In comparison, 6 percent can afford to pay above 400,000 Naira for rented housing annually.

The relationship between housing affordability and housing quality was further examined. The former was measured by the house type (number of bedrooms in the apartment) while the latter by the calculated percentage of income used for rent by the residents. A null hypothesis was stated that there is no significant relationship between rent affordability and housing quality. The two variables were measured as nominal data. The output of the Chi-square analyses as presented on Table 1 shows that the Pearson Chi-square statistic $(f)=11.463$, $p$-value $=0.022(p<0.05)$. A p-value less than the alpha or significance level implies that the variables are dependent. Thus, there is a significant statistical relationship between housing affordability and housing quality. The alternate hypothesis was thus accepted. This implies that the type of house a city dweller in Calabar stays in is greatly influenced by the resident's income. This does not disprove other factors that might influence a city dweller's preference of house types, such as household size or just mere choice. The cross-tabulation analysis presented in Table 2 shows that 29 and 21.8 percent of residents who spend less than and greater than 30 percent of their income on rent respectively reside in single-room apartments. About 40.3 percent of residents who spend less than 30 percent of their income and 33.6 percent who spend more than 30 percent stay in onebedroom houses. Notably on the cross-tabulation are the residents who spend more than 30 percent and reside in highcost houses such as the 23.9 percent, 16 percent, and 4,6 percent who reside in two-bedroom, three-bedroom, and duplex apartments, respectively. City dwellers pay more for housing for many reasons such as the need for more space, the quality of the house, or just because of taste. 


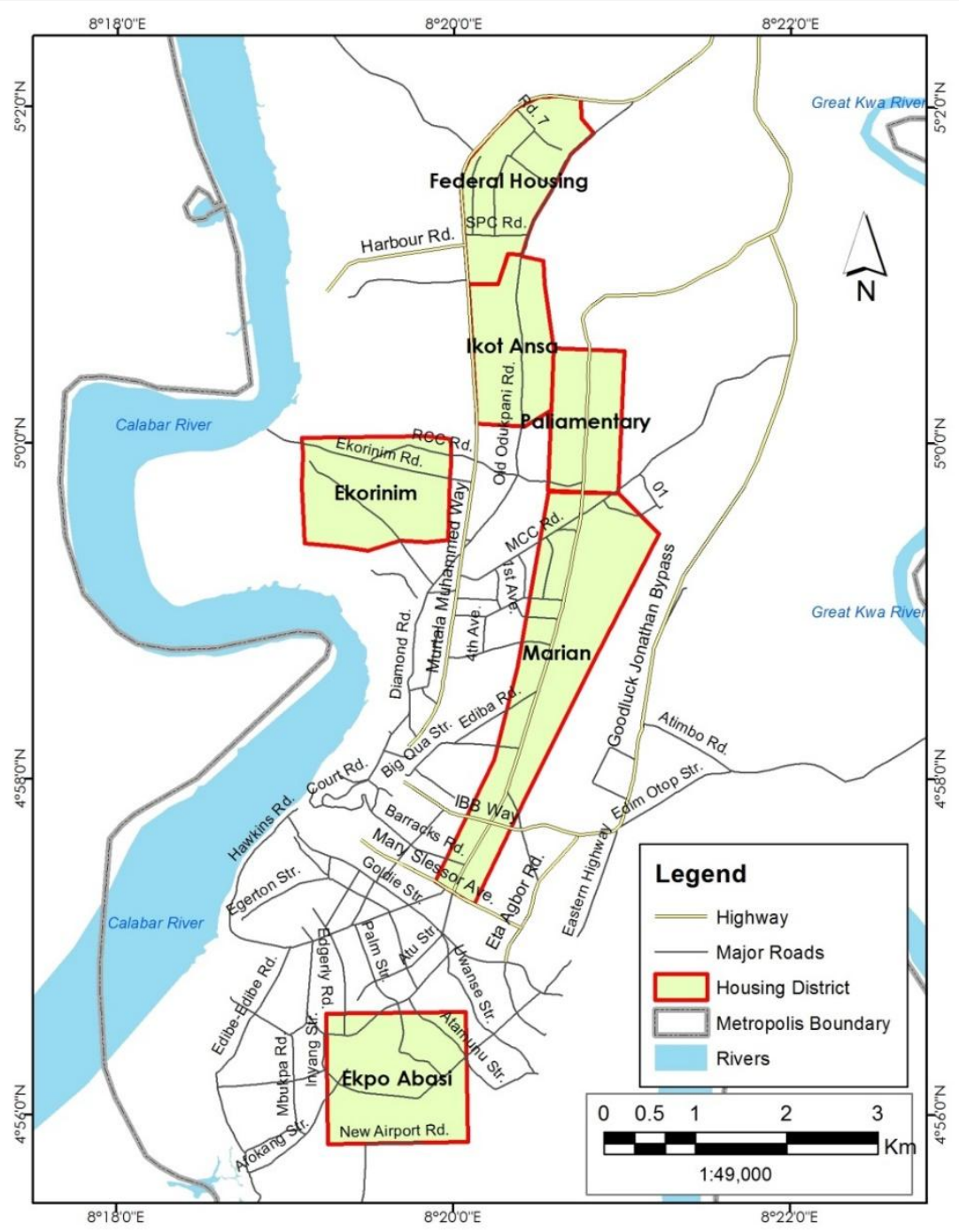

Figure 2: Delineated housing districts in Calabar Metropolis

Source: Author's field survey, 2021

Table 1: Chi-Square output for the relationship between housing affordability and quality

\begin{tabular}{ll}
\hline & Value dfAsymp. Sig. (2-sided) \\
\hline Pearson Chi-Square & 11.4634 .022 \\
\hline Likelihood Ratio & 11.9004 .018 \\
\hline Linear-by-Linear Association.705 1.401 \\
\hline N of Valid Cases & 300 \\
\hline
\end{tabular}

Source: Author's fieldwork, 2021

Table 2: Housing affordability and housing quality cross-tabulation

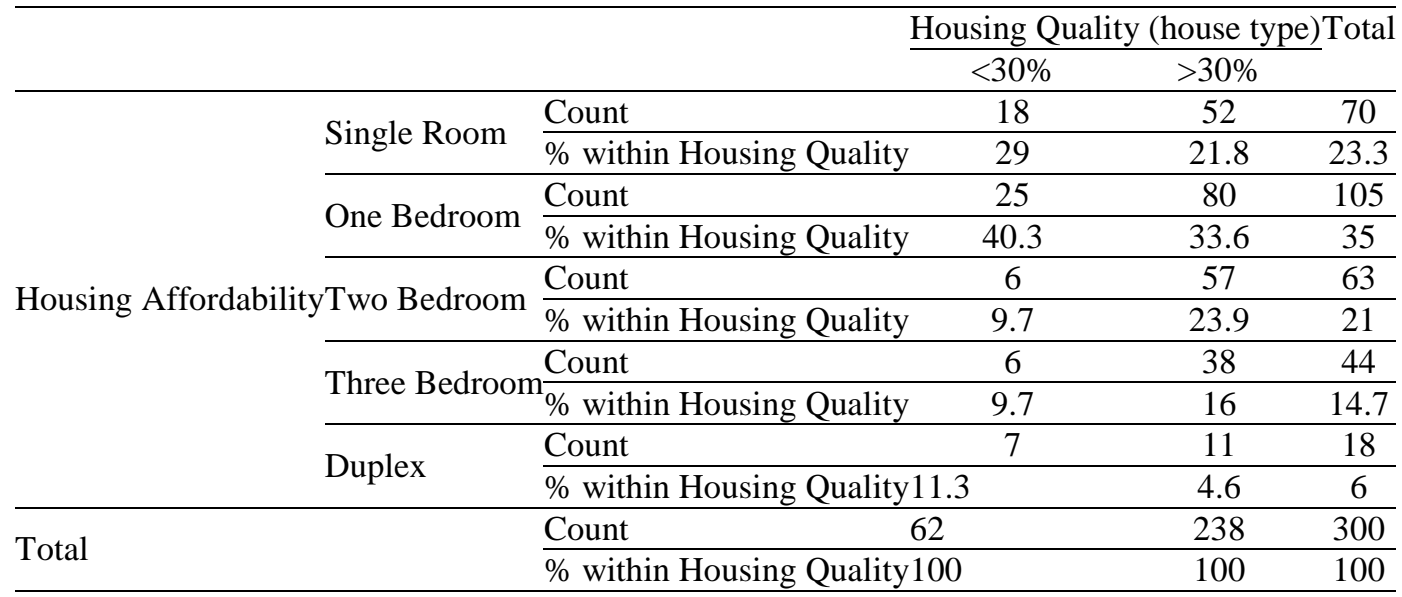

Source: Author's fieldwork, 2021 
The second hypothesis was formulated to assess housing affordability in Calabar in line with Kutty's (2005) position that housing affordability can be interpreted as the relationship between household income and housing expenditure. The hypothesis stated no significant relationship between average monthly income and expenditure on rented residential housing in Calabar. This was to examine the relationship between how much a Calabar resident avails for accommodation based on accrued income. The two variables were measured as nominal data. The output of the Chisquare analyses presented on Table 3 shows that the Pearson Chi-square statistic (f) $=539.473$, $\mathrm{p}$-value $=0.000$ ( $\mathrm{p}<$ 0.05). This derivation denotes that the variables are dependent, thus enough evidence to infer a significant statistical relationship between average monthly income and average money expended on rented residential housing in the metropolis. Therefore, the stated null hypothesis is rejected. This means that the income of residents in Calabar greatly influences how much is paid for housing.

The cross-tabulation executed and presented in Table 4 supports the outcome of the Chi-square test and buttresses the situation in the city. As shown, 100 percent of residents who less than 100,000 Naira on rent annually earn less than 10,000 Naira monthly, and expectedly, no respondent who makes less than 10,000 Naira pay above 200,000 Naira for rent yearly. Also, 55.7 percent of respondents who make 51,000 to 100,000 monthly spend between 101,000 to200,000 Naira annually, and 34.1 percent of residents who make within the same category spend between 201,000 to 300,000 Naira annually. More so, 75.9 percent of residents who spend more than 200,000 Naira make between 101,000 to 150,000 Naira annually, and no resident who makes less than 200,000 Naira resides home in the former price range. Further, 67.7 and 23.3 percent ( 9 percent of all counts) of residents who pay more than 400,000 Naira make above 150,000 and 200,000 Naira monthly. Visibly, no resident who makes less than 150,000 Naira resides in houses with annual rents of more than 200,000 Naira.

The 2002 New National Housing and Urban Development Policy (NNHUDP), (see Aribigbola, 2008), advocates a maximum expenditure of 20 percent monthly income on housing. This is hardly the case as many Nigerians expend far more than 20 percent of their monthly income on the high price of housing units as many studies demonstrated. The causes of the high price of housing units range from the cost of land, building materials, to housing-related infrastructure, and so on (Ibem, 2010; Ugochukwu \& Chioma, 2015; Lawal \& Adekunle, 2018; Bons, Onochie \& Nzewi, $\underline{2019)}$

\section{Housing Choice Consideration}

The reasons for choosing a residential apartment are enormous. Some of these reasons were considered in this study as listed 1 to 11 in Table 5. The reasons were assessed for the different housing districts delineated for the survey study. In Ekpo Abasi district, the most prevailing reason why residents choose a house was affordability, while they care less about safety and security. This is due to the low cost of housing in the area and the location of the Cross River University of Technology. In Marian district, the most pressing reason is business and livelihood: This is apparently due to the closeness to business ventures since Marian is a commercial hub in Calabar. Some residents prefer to reside close to their shops and offices. The case of Ikot Ansa district is different. Here, infrastructure (that is, the quality of a building and the outlook of the environment) is the most apparent reason given by the respondents. Proximity to the workplace and ownership of houses were also prominent reasons in Ikot Ansa.

Table 3: Chi-Square of the relationship between average monthly income and expenditure on housing.

\begin{tabular}{llll}
\hline & Value & df & Asymp. Sig. (2-sided) \\
\hline Pearson Chi-Square & 539.473 & 16 & 0.000 \\
\hline Likelihood Ratio & 428.597 & 16 & .000 \\
\hline Linear-by-Linear Association & 210.917 & 1 & .000 \\
\hline N of Valid Cases & 300 & & \\
\hline
\end{tabular}

Source: Author's fieldwork, 2021

Table 4: Average monthly income and expenditure on rented residential housing cross-tabulation

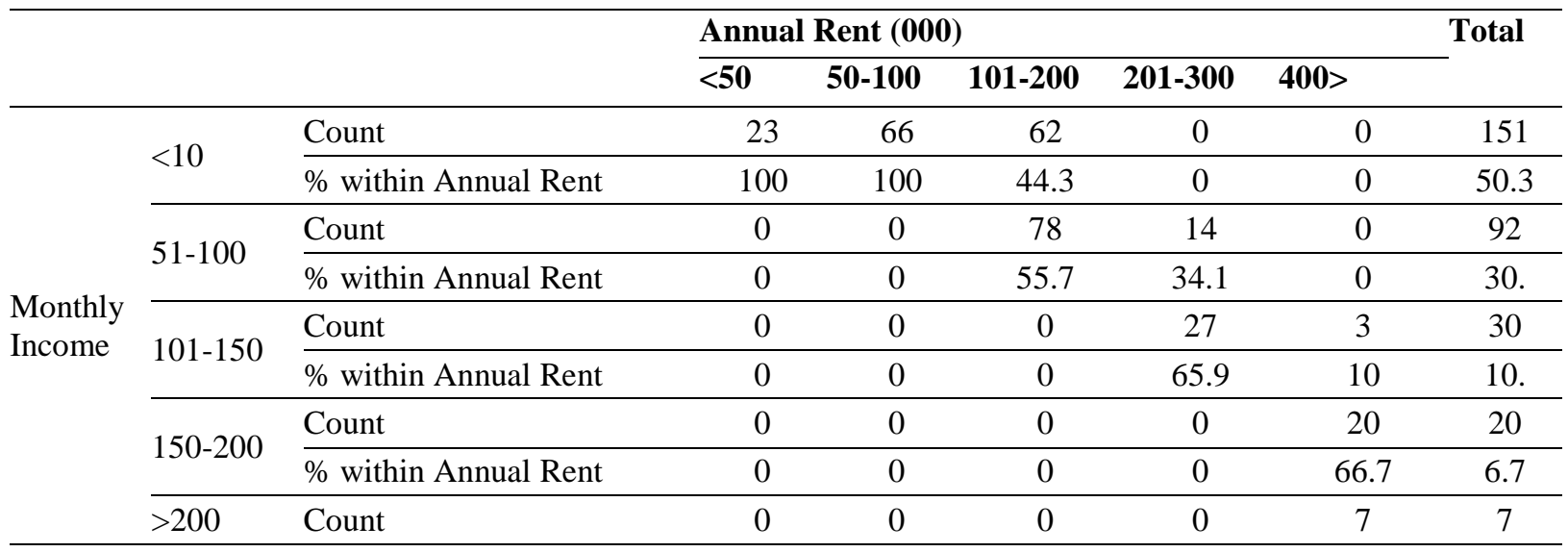




\begin{tabular}{llcccccc}
\hline & \% within Annual Rent & 0 & 0 & 0 & 0 & 23.3 & 2.3 \\
\hline \multirow{2}{*}{ Total } & Count & 23 & 66 & 140 & 41 & 30 & 300 \\
\cline { 2 - 7 } & $\%$ within Annual Rent & 100 & 100 & 100 & 100 & 100 & 100 \\
\hline
\end{tabular}

Source: Author's fieldwork, 2021

Table 5: Housing choice consideration in 6 delineated districts of Calabar (in percentages)

\begin{tabular}{llccccccc}
\hline $\mathrm{s} / \mathrm{n}$ & Variable & $\begin{array}{c}\text { Ekpo- } \\
\text { Abasi }\end{array}$ & Marian & $\begin{array}{c}\text { Ikot } \\
\text { Ansa }\end{array}$ & Ekorinim & Parliamentary & $\begin{array}{c}\text { Fed } \\
\text { Housing }\end{array}$ & $\begin{array}{c}\text { Agg. } \\
\mathbf{\%}\end{array}$ \\
\hline 1 & Business/livelihood & 1.7 & 7.3 & 1.3 & 1.7 & 1 & 0.7 & 13.7 \\
2 & Safety/security & 0.3 & 1 & 1.3 & 5 & 3.3 & 5 & 15.9 \\
3 & Affordability of housing & 10 & 1.7 & 2.3 & 1.7 & 1.7 & 0.3 & 17.7 \\
4 & Owner-occupier & 0 & 0 & 3.3 & 0 & 0.3 & 1.3 & 4.9 \\
5 & Proximity to workplace & 1 & 1 & 3.3 & 1 & 1.7 & 0.3 & 8.7 \\
6 & Proximity to child's school & 0.3 & 1.7 & 0 & 0.3 & 1.7 & 1 & 5 \\
7 & Near kinsmen & 0 & 0 & 0 & 0.3 & 0.3 & 0.3 & 0.9 \\
8 & Near the place of worship & 0.3 & 0 & 0 & 0 & 0.3 & 0.3 & 0.9 \\
9 & Environment & 3 & 4 & 5 & 6.7 & 6.3 & 6.7 & 31.7 \\
10 & Near recreational/natural area & 0 & 0 & 0 & 0 & 0 & 0.3 & 0.3 \\
11 & Mixed land-use area & 0 & 0 & 0 & 0 & 0 & 0.3 & 0.3 \\
\hline
\end{tabular}

Source: Author's fieldwork, 2021

Infrastructure was again a significant factor in Ekorinim as well as safety and security. In the Parliamentary district, where most of the buildings are of good quality with middle-income settlers, infrastructure was the most given reason followed by safety and security. Federal housing district houses mostly high-income immigrants with high-quality buildings. In the Federal Housing scenario, infrastructure was again the leading reason for housing consideration, safety, and security. Figure 3 further buttresses the spatial spread of these considerations in the six districts. For most of the districts, the map shows sharp color progressions from very light blue. This represents the first three variables of consideration. The dark blue represents variable number nine as shown in Table 5. This depicts that, just as aggregated in the table, infrastructure had the highest percentage (31.7 percent), followed by the affordability of housing (17.7 percent), safety and livelihood (15.9 percent), and business/livelihood (13.7 percent). Nearness to recreational/natural areas and mixed land use were the most minor reasons for housing choice consideration in the city and were barely represented on the map.

\section{CONCLUSION AND RECOMMENDATIONS}

Man needs shelter and this accommodation is needed where economic opportunities prevail, including informal activities, such as in urban areas. When the metropolitan area becomes saturated, it becomes expedient for the teeming population to occupy the pockets of idle lands. The proliferation of substandard houses becomes the last resort for lowincome urban dwellers with fragile livelihoods who cannot afford decent houses in the city. In Calabar, the rising cost of housing and land has become a source of concern to all stakeholders.

This study revealed that housing in the metropolis is not affordable as about 80 percent of residents use more than 30 percent of their income for housing. This is so because payments are low compared to housing costs., The one-bedroom flat becomes the most predominant housing type in the city as it is somewhat affordable and can accommodate the swarming youth population and families alike. The quality of house a city dweller in Calabar chooses to stay in is showed to be significantly influenced by income and income also showed to significantly affect how much is paid for housing greatly. Infrastructure was revealed to be the most significant determinant of resident's choice of accommodation, followed by the affordability of housing, safety and livelihood, and location of business place., However, affordability stood out to be most significant for residents of the Ekpo Abasi area.

It is recommended that the relevant government agencies intensify efforts not only to provide standard and affordable housing but initiate policies and programs that would encourage private developers to venture into the provision of lowcost housing in the metropolis. This can be replicated in many other cities of the developing world. Also, regulations must be put in place to deter landlords from preying on tenants who before now are at the mercy of their homeowners. This phenomenon is not unique to the study area, but across many cities in the developing world. Housing standards should also be enforced by the relevant agencies of government to ensure that its quality is not compromised. Most importantly, the results of this study should be adopted as a decision-making guide. The reasons why people shy away or embrace some residential locations should be noted to aid necessary improvements in what is lacking in such negated areas. For example, public infrastructure and security call for improvement in the Ekpo Abasi area since housing is more affordable therein and low-cost housing is provided in some other areas (such as the location of the abandoned Ikot Ekpo housing estate in the far northern flank of the city, which requires renovation) to reduce congestion in the heart of the city. 


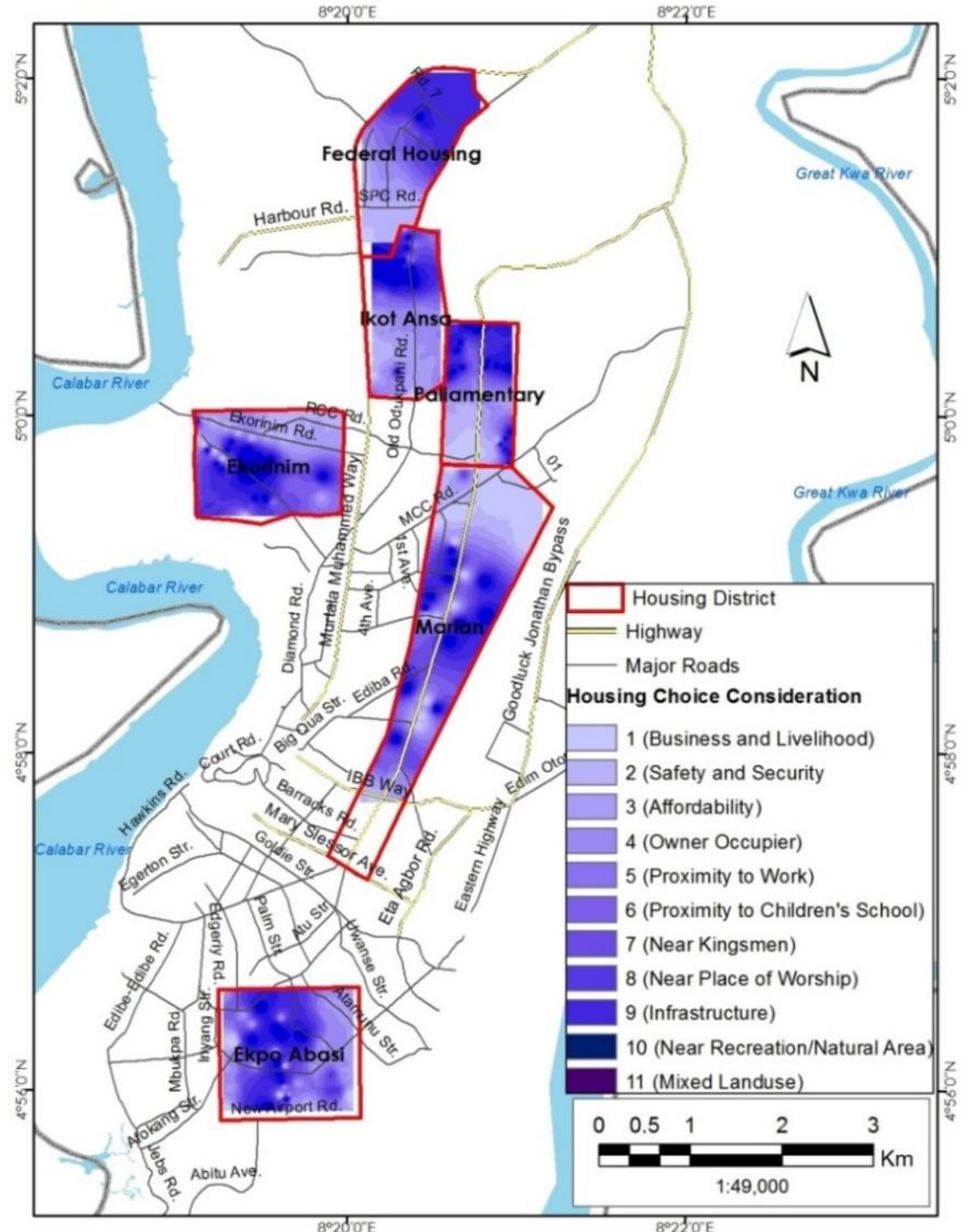

Figure 3: Variation in the housing choice consideration in 6 delineated districts of Calabar

Source: Author's fieldwork, 2021

\section{AUTHOR'S CONTRIBUTION}

Author 1: Analysis of data, reporting of findings, production of maps and final editing of manuscript.

Author 2: Fieldwork and data collection, writing of draft manuscript and participation in map production.

\section{REFERENCES}

1. Adabre, M.A., Chan, A.P. (2019). Critical success factors (CSFs) for sustainable affordable housing. Build. Environ., 156, 203-214. https://doi.org/10.1016/j.buildenv.2019.04.030

2. Adegun, O.B., Adedeji, Y.M.D. (2017). Review of economic and environmental benefits of earthen materials for housing in Africa. Front. Arch. Res., 6, 519-528. https://doi.org/10.1016/j.foar.2017.08.003

3. Agbor, E. A, Ojikpong, B. E, Okon, I, \& Obia, A. E. (2016). Impact of socio-economic characteristics on the quality of housing environment in Ikom Urban, Cross River State, Nigeria. American International Journal of Contemporary Research, 6(6), 19-29.

4. Ajanlekoko, J. S. (2001). Sustainable housing development in Nigeria-The financial and infrastructural implication. International Conference on Spatial Information for Sustainable Development, Nairobi, Kenya. 2-5 October 2001.

5. Ajanlekoko, J. S. (2001). Sustainable housing development in Nigeria-The financial and infrastructural implication. International Conference on Spatial Information for Sustainable Development, Nairobi, Kenya. 2-5 October, https://www.fig.net/resources/proceedings/2001/nairobi/ajanlekoko-CMWS1-1.pdf

6. Akintoye, A. (2006). Public partnership for sustainable development of infrastructure in developing countries. The Built Environment: Innovation, Policy and Sustainable Development. 433-442. 
7. Animashaun, I. A. (2010) Provision of residential housing and environmental development in Calabar: Policy Contradictions. Retrieved from: http://www.readperiodicals.com/201001/2307422931.htm

8. Aribigbola, A. (2008) Housing policy formulation in developing countries: Evidence of programme implementation from Akure, Ondo State Nigeria. J. Hum. Ecol., 23, 125-134. https://doi.org/10.1080/09709274.2008.11906063

9. Ayedun, C. A. \& Oluwatobi, A. O. (2011). Issues and challenges militating against the sustainability of affordable housing provision in Nigeria. Business Management Dynamics, 1(4), 1-8.

10. Bons, O.N., Onochie, A.O., Nzewi, N.U. (2019). Where is Home for the Abuja, Nigeria Urban Poor? Int. J. Trend Sci. Res. Dev., 3, 45-56. https://doi.org/10.31142/ijtsrd21656

11. Bujang, A. A. (2006) in Bujang, A. A., Zarin, H. A. \&Jumadi, N. The relationship between demographic factors and housing affordability. Malaysian Journal of Real Estate, 5(1), 49-58.

12. Chan, A.P., Adabre, M.A. (2019). Bridging the gap between sustainable housing and affordable housing: The required critical success criteria (CSC). Build. Environ, 151, 112-125. https://doi.org/10.1016/j.buildenv.2019.01.029

13. Demographia World Urban Areas (2017). Available online: http://www.demographia.com/db-worldua.pdf (accessed on 15 May 2017).

14. Demographia World Urban Areas (2017). Built-Up Urban Areas or World Agglomerations. 17th Annual Edition, Available online: http://www.demographia.com/db-worldua.pdf (accessed on 15 May 2017).

15. ESRI (2013). An introduction to interpolation methods, ArcGIS for Desktop Help, 1995-2013.

16. ESRI (2013). An introduction to interpolation methods, ArcGIS for Desktop Help, 1995-2013. Available: https://desktop.arcgis.com/en/arcmap/10.3/tools/spatial-analyst-toolbox/understanding-interpolationanalysis.htm

17. Ezennia, I. S., \& Hoskara, S. O. (2019). Exploring the severity of factors influencing sustainable affordable housing choice: evidence from Abuja, Nigeria. Sustainability, 11(20), 5792. https://doi.org/10. 3390/su11205792

18. Ezennia, I.S. \& Hoskara, S.O. (2019). Methodological weaknesses in the measurement approaches and concept of housing affordability used in housing research: A qualitative study. PLoS ONE, 14, 221246. https://doi.org/10.1371/journal.pone.0221246

19. Gan, X., Zuo, J., Wen, T., \& She, Y. (2019). Exploring the adequacy of massive constructed public housing in China. Sustainability, 11(7), 1949. https://doi.org/10.3390/su11071949

20. Gan, X.; Zuo, J.; Wu, P.; Wang, J.; Chang, R.; \& Wen, T. (2017). How affordable housing becomes more sustainable? A stakeholder study. J. Clean. Prod., 162, 427-437. https://doi.org/10.1016/j.jcle pro.2017.06.048

21. Geissler, S.; Österreicher, D.; Macharm, E. (2018). Transition towards energy efficiency: Developing the Nigerian building energy efficiency code. Sustainability, 10, 2620. https://doi.org/10.3390/su10082620

22. Ghazali, E.M.; Ngiam, E.Y.L.; Mutum, D.S. (2019). Elucidating the drivers of residential mobility and housing choice behaviour in a suburban township via the push-pull-mooring framework. J. Hous. Built Environ., 1-27. https://doi.org/10.1007/s10901-019-09705-8

23. Ibem, E.O. (2010). An assessment of the role of government agencies in public-private partnerships in housing delivery in Nigeria. J. Constr. Dev. Ctries., 15, 23-48.

24. Jansen, S.J.T. \& Coolen, H.C.C.H. (2011). Goetgeluk, W.R. The Measurement and Analysis of Housing Preference and Choice; Springer: London, UK. https://doi.org/10.1007/978-90-481-8894-9

25. Kährik, A., Temelova, J., Kadarik, K., Kubes, J. (2016). What attracts people to inner-city areas? The cases of two post-socialist cities in Estonia and the Czech Republic. Urban Stud., 53, 355-372. https://doi.org/10.1177/0042098014567444

26. Kalu, I. E, Agbarakwe, H. U. \& Anowor, O. F. (2014). National Housing Policies and the realization of improved housing for all in Nigeria. Asian Development Policy Review, 2(3),47-60. https://doi.org/10.18488/journal.107.2014.23.47.60

27. Karlan, D. \& Morduch, J. (2014). Macroeconomics; McGraw Hill Education: New York, NY, USA.

28. Kutty, N. K. (2005). A new measure of housing affordability: estimates and analytical results. Housing Policy Debate, 16(1), 113-142. https://doi.org/10.1080/10511482.2005.9521536

29. Lawal, A.O.; Adekunle, I.A. (2018). Access to Land and the Delivery of Affordable Housing in Nigeria: An Assessment of the Federal Housing Authority (FHA) in Abuja, 1991 to 2013. SAGE Open, 8. https://doi.org/10.1177/2158244018777281

30. Makinde, O.O. (2014). Housing delivery system, need and demand. Environ. Dev. Sustain., 16, 49-69. https://doi.org/10.1007/s10668-013-9474-9

31. Mulliner, E., Maligne, V. (2015). An analysis of professional perceptions of criteria contributing to sustainable housing affordability. Sustainability, 7, 248-270. https://doi.org/10.3390/su7010248

32. Napoli, G. (2017). Housing Affordability in Metropolitan Areas. The Application of a Combination of the Ratio Income and Residual Income Approaches to Two Case Studies in Sicily, Italy. Buildings, $7,95$. https://doi.org/10.3390/buildings7040095

33. National Population Commission (2006). Federal Government of Nigeria, Abuja-Nigeria.

34. O’Sullivan, A., Sheffrin, S., Perez, S. (2013). Microeconomics: Principles, Applications, and Tools, 8th ed.; Prentice-Hall: San Francisco, CA, USA. 
35. Ojoko, T. I. T. \& Okon, I. (2018). Housing-Related Urban Poverty in Nyangasang and Anantigha Areas of Calabar Metropolis, Cross River State, Southern Nigeria. International Journal of Innovative Research and Advanced Studies (IJIRAS), 5(6), 180-187.

36. Okewole, I. A., Ajayi, A., Daramola, A., Odusanmi, K. \& Ogunba, O. (Eds.) (2016). Convenient University, Ota, Nigeria.

37. Okewole, I. A., Ajayi, A., Daramola, A., Odusanmi, K. \& Ogunba, O. (Eds.) (2016). Public partnership for sustainable development of infrastructure in developing countries. The Built Environment: Innovation, Policy and Sustainable Development. 433-442. Okewole, I. A., Ajayi, A., Daramola, A., Odusanmi, K. \& Ogunba, O. (Eds.) Convenient University, Ota, Nigeria.

38. Okon, I. E., C Ogba \& T Adejumo (2012). Inadequate land policies and the impact of poverty on housing quality in Calabar Municipality, Cross River State, Nigeria. International Journal of Research and Advancement in Environmental Science, 2(1), 83-92.

39. Olanrewaju, A. \& Woon, T.C. (2019). An exploration of determinants of affordable housing choice. International Journal of Housing Markets and Analysis, 10(5), 703-723. https://doi.org/10.1108/IJHMA-112016-0074

40. Olanrewaju, A., Tan, S.Y., Abdul-Aziz, A.R. (2018). Housing providers' insights on the benefits of sustainable affordable housing. Sustain. Dev., 26, 847-858. https://doi.org/10.1002/sd.1854

41. Olanrewaju, A., Woon, T.C. (2017). An exploration of determinants of affordable housing choice. Int. J. Hous. Mark. Anal., 10, 703-723.

42. Olotuah, A. O. \& Adedeji, Y. M. D. (2007). An evaluation of the accessibility of low-income earners to housing finance in Nigeria. D-Review.net.

43. Olotuah, A. O., \& Adedeji, Y. M. D. (2009). An evaluation of the accessibility of low-income earners to housing finance in Nigeria. European Scientific Journal, 8, 12-25.

44. Omojinmi, I. O. (2000). SINA Technical Workshop on Housing Co-operatives, Nairobi. 6-17 October.

45. Omole, F. K. (2001). An assessment of housing conditions and socio-economic lifestyles of slum dwellers in Akure, Nigeria. Contemporary Management Research, 6(4) 237-290. https://doi.org/10.7903/cmr.2980

46. Onibokun, A.G (1985). Public housing delivery system in Nigeria (1979-1983). A critical review. Housing in Nigeria, Onibokun, A.G(Ed). Nigeria Institute of Social and Economic Research, NISER, Ibadan, 429-446.

47. Onibokun, A. G. (1985). Public Housing Delivery System in Nigeria (1979-1983). A Critical Review. Housing in Nigeria, Onibokun, AG (Ed.) Nigerian Institute of Social and Economic Research, NISER, Ibadan, 429-446.

48. Parkin, M. (2011). Microeconomics, Pearson Education Limited, Harlow. In Proceedings of the 8th International Conference on Environmental Engineering, Vilnius, Lithuania, 19-20 May 2011; pp. 966-973. Available online: https://tinyurl.com/y6os5plc (accessed on 4 March 2019).

49. Parkin, M. (2011). Microeconomics, Pearson Education Limited, Harlow. In Proceedings of the 8th International Conference on Environmental Engineering, Vilnius, Lithuania, 19-20 May, 966-973. Available online: https://tinyurl.com/y6os5plc (accessed on 4 March 2019).

50. Saunders, M., Lewis, P. \& Thornhill, A. (2007). Research methods for business students. Fourth Edition. Pearson Education Limited, Edinburg Gate, Harlow, Essex, England.

51. Sirgy, M.J., Grzeskowiak, S., Su, C. (2005). Explaining housing preference and choice: The role of selfcongruity and functional congruity. J. Hous. Built Environ., 20, 329-347. https://doi.org/10.1007/s10901-0059020-7

52. Smith, S. M. (2000). Determining sample size: how to ensure you get the correct sample size. URL: http://success.qualtrics.com/rs/qualtrics/images/determining-sample-size.pdf

53. Statistics New Zealand (2015). Measuring housing quality: Potential ways to improve data collection on housing quality in New Zealand Available from www.stats.govt.nz.

54. Stone, M. E. (2006). What is housing affordability? The case for the residual income approach. Housing Policy Debate, 17(1) 151-184. https://doi.org/10.1080/10511482.2006.9521564

55. Struyk R.J. (2005). Home purchase affordability and mortgage finance. In J. Hegedus \& R.J. Struyk, (Eds). Housing finance: New and old model in central Europe, Russian and Kazakhstan. Budapest: Open Society Institute, 65-77.

56. Ugochukwu, I.B., Chioma, M.I.B. (2015). Local building materials: Affordable strategy for housing the urban poor in Nigeria. Procedia Eng., 118, 42-49. https://doi.org/10.1016/j.proeng.2015.08.402

57. Vehbi, B.O., Hoskara, E., Hoskara, S.O. (2010). A Theoretical Approach for Assessing Sustainability in Housing Environment. Open House Int., 35, 26-36. https://doi.org/10.1108/OHI-01-2010-B0003

58. Woetzel, J., Ram, S., Mischke, J., Garemo, N., Sankhe, S. A (2014). Blueprint for Addressing the Global Affordable Housing Challenge; McKinsey Global Institute: New York, NY, USA.

59. World Commission on Environment and Development (1987). Our Common Future. Oxford: Oxford University Press.

60. World Commission on Environment and Development (1987). By World commission on environment and development, London, Oxford University Press, pp. 383.

61. Yao, C. (2011). Measuring housing affordability in Beijing. M.Sc. Thesis, Department of Real Estate and Construction Management of Building and Construction Economic, Royal Institute of Technology, Stockholm. 
62. Yao, C. (2011). Measuring housing affordability in Beijing. M.Sc. Thesis, Department of Real Estate and Construction Management of Building and Construction Economic, Royal Institute of Technology, Stockholm, https://www.diva-portal.org/smash/get/diva2:458169/FULLTEXT01.pdf

63. Zinas, B.Z., Jusan, M.B.M. (2012). Housing choice and preference: Theory and measurement. Procedia-Soc. Behav. Sci., 49, 282-292. https://doi.org/10.1016/j.sbspro.2012.07.026

64. Zyed, Z.A.S., Aziz, W.N.A.W.A., Hanif, N.R. (2016). Housing affordability problems among young households. J. Surv. Constr. Prop., 7, 1-18. https://doi.org/10.22452/jscp.vol7no1.2 